\title{
Changes in the Prevalence of Natural Paramphistomum Cercariae Infection in Indoplanorbis and Lymnaea Intermediate Hosts Influenced by Meteorological Factors
}

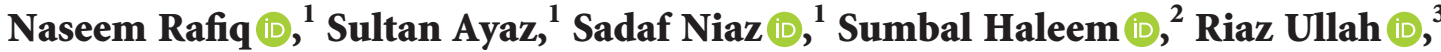 \\ Ahmed Bari $\left(\mathbb{D},{ }^{4}\right.$ Mohammed Bourhia $\left(\mathbb{D},{ }^{5}\right.$ and Essam A. Ali $^{4}$ \\ ${ }^{1}$ Department of Zoology, Abdul Wali Khan University, Mardan, Pakistan \\ ${ }^{2}$ Department of Zoology, Kohat University of Science and Technology, Kohat, KP, Pakistan \\ ${ }^{3}$ Department of Pharmacognosy, College of Pharmacy, King Saud University, Riyadh, Saudi Arabia \\ ${ }^{4}$ Department of Pharmaceutical Chemistry, College of Pharmacy, King Saud University, Riyadh, Saudi Arabia \\ ${ }^{5}$ Laboratory of Chemistry-Biochemistry, Environment, Nutrition, and Health, Faculty of Medicine and Pharmacy, \\ Hassan II University, Casablanca B.P. 5696, Morocco
}

\begin{abstract}
Correspondence should be addressed to Naseem Rafiq; naseem_rafiq2000@yahoo.com and Mohammed Bourhia; bourhiamohammed@gmail.com
\end{abstract}

Received 3 June 2021; Revised 16 December 2021; Accepted 18 January 2022; Published 3 February 2022

Academic Editor: Pedro P. Chieffi

Copyright (C) 2022 Naseem Rafiq et al. This is an open access article distributed under the Creative Commons Attribution License, which permits unrestricted use, distribution, and reproduction in any medium, provided the original work is properly cited.

Paramphistomosis is a neglected ruminant parasitic disease caused by trematodes known as Paramphistomum, which has a diheteroxenic life cycle involving freshwater snail genera, i.e., Planorbis and Lymnaea as the intermediate host and mammals as the definitive host. Snail vector distribution, infection with Paramphistomum spp. cercariae, preferred habitat, and their relationship with certain meteorological factors were not investigated in the province Khyber Pakhtunkhwa of Pakistan. Therefore, this study is designed to evaluate the effects of meteorological factors on the occurrence and severity of Paramphistomum spp. cercariae in Indoplanorbis and Lymnaea intermediate snail hosts. For this purpose, a cross-sectional survey was conducted from October 2018 to September 2019, and snails were collected and then identified using snail shell morphology; their infection with Paramphistomum spp. cercariae was determined through microscopy; and descriptive statistics were used to estimate the prevalence of infection and evaluate their occurrence relationship with a certain meteorological factors including temperature, humidity, rainfall, and pan evaporation in different districts of the above-mentioned province of Pakistan, i.e., adjacent areas of Bara and Kabul rivers in district Nowshehra, Kabul River (Sardaryab) of district Charsadda, Kalpani River of district Mardan, and Indus River (Hund) of district Swabi. A total of 2,706 Indoplanorbis (1539) and Lymnaea (1167) snails were collected, in which overall $10.30 \%$ shed Paramphistomum spp. cercariae. The highest infection rate was found in the river of district Swabi (13.20\%), while the lowest in adjacent rivers of district Nowshehra (8.19\%). Meteorological factors play an essential role in the causation of Paramphistomum spp. infection, parasitic reproduction, vector growth, and survival. Due to these factors, high significant prevalence was found in the summer season (11.83), followed by autumn (11.25), which might be due to optimum temperature, relative humidity, and rainfall $(p<0.05)$. It was concluded from the study that meteorological factors contribute to the prevalence of Paramphistomum species in the Indoplanorbis and Lymnaea, which act as vectors for the disease paramphistomosis, which may lead to the increased intensity of infection outbreaks of the parasite population in humans and domestic animals.

\section{Introduction}

Paramphistomosis is a neglected ruminant parasitic disease with a broad geographic distribution caused by Trematoda that belongs to the Paramphistomatidae family. The genus name Paramphistomum is a derivative of a Greek word amphistomes, meaning paired mouth [1]. The life cycle of Paramphistomum involves a diheteroxenic cycle including snails as the intermediate host and mammals as the definitive host. The snail species may be Lymnaea bulimoides, 
Bulinus spp., and Planorbis planorbis [2]. The shape of a live, mature worm is conical, and the color is pink. Its length ranges from 5 to $12 \mathrm{~mm}$. The front end bears an oral sucker, while there is a large ventral sucker at the rear end. It has a convex dorsal surface and a concave ventral surface [3]. After hatching in water, the egg (miracidia) infects freshwater snails (bulinid or planorbid), which are their intermediate [4]. Adult flukes are usually considered nonpathogenic to their hosts; however, the invasion of immature worms through duodenal mucosa induces serious enteritis, likely necrosis and hemorrhage, and is responsible for anorexia, polydipsia, unthriftiness, severe diarrhea, and mortality in the definitive host. [5]. Paramphistomosis leads to lower conversion of nutrition and a decrease in the production of weight and milk in ruminant grazing [6]. Paramphistomosis prevalence is high in all subtropical and tropical regions, particularly in Russia, Australia, Eastern Europe, Asia, and Africa [5, 7-9]. The prevalence is 30-60\% in some regions of Asia including Pakistan $[5,10,11]$. Gastrointestinal helminths, including Paramphistomum species, were recorded to be 25.1 to 92 percent in various areas during different times in Pakistan [10, 12-15].

The species of Paramphistomum have a complex life cycle that requires freshwater snails as an intermediate host for completion of its life cycle. Therefore, the transmission of paramphistomosis can be minimized by controlling the infection in the intermediate host, as the snails are mobile and able to spread the infection in an ungrazed posture. The prevalence of the Paramphistomum species may be less than 2 percent and may grow to 20 percent or sometimes higher if the conditions for hatching of the eggs in the intermediate snail host are sufficient [15].

Prevalence of Paramphistomum and its extent depend on specific factors. Various studies show that climate change can modify the geographic distribution of parasite infections and potentially cause drastic changes to their hosts. The life cycle and prevalence of the Paramphistomum spp. depend on several meteorological factors. This led to the creation of the prediction method based on meteorological data prevising the timing and severity of the infection [16]. Such predictions will serve as the basis for the system of animal control. Temperature, humidity, rainfall, water velocity, and habitat stability are some of the main factors determining the production of many parasite infections [17]. These factors affect the metabolic system of both the parasite and the host (snail), interfering with the rate of growth, survival, and reproduction of snails $[18,19]$. Snails belonging to the genus Indoplanorbis and Lymnaea are widespread in different locations in Pakistan and act as an intermediate host for the transmission of various parasite infections including paramphistomosis. However, to the authors' best knowledge, no previous study on the prevalence of Paramphistomum spp. cercariae in the intermediate snail host was conducted in Khyber Pakhtunkhwa, Pakistan.

In the backdrop of the above discussion, this study is designed to evaluate the effects of meteorological factors on the occurrence and severity of Paramphistomum spp. cercariae in Indoplanorbis and Lymnaea intermediate snail hosts.

\section{Materials and Methods}

2.1. Study Design. Duration of the present study was from October 2018 to September 2019, and freshwater Indoplanorbis and Lymnaea intermediate snail hosts infected with Paramphistomum spp. cercariae were collected from different districts including adjacent areas of Bara and Kabul rivers in district Nowshehra, Kabul River (Sardaryab) of district Charsadda, Kalpani River of district Mardan, and Indus River (Hund) of district Swabi of province Khyber Pakhtunkhwa, Pakistan.

\subsection{Indoplanorbis and Lymnaea Collection and Identification.} For the collection of the Indoplanorbis and Lymnaea intermediate snail hosts, a scoop net was used, which consists of a metal ring with a shallow dip net attached to a handle used in fishing. The diameter of the ring was $30 \mathrm{~cm}$, while the length was $36 \mathrm{~cm}$. A wire net of $16 \mathrm{~m}$ ash per inch was attached to the metal ring. A total of 2,706 snails were collected both from the immersed zones and shallow or stagnant waters of each area. These snails were transferred to polythene bags filled with some water and vegetation and were transported to the Laboratory of Parasitology, Department of Zoology, Abdul Wali Khan University, Mardan, on the same day. The collected snails were kept in water tanks provided with vegetation such as Vallisneria spiralis and Hydrilla verticillata and constantly aerated. Certain ecological parameters were recorded during snail collection, particularly temperature and $\mathrm{pH}$ of the water. Majority of the snails were attached to the back side of the leaves found on the side walls of the pond at the depth of 1-3 feet. The snails were found in shaded areas of ponds. The collected snails were identified to the genus level through keys provided by the guide entitled as "Field guide to the non-marine molluscs of Southeastern Australia" [20].

\subsection{Examination of Indoplanorbis and Lymnaea Intermediate} Snail Hosts for Paramphistomum spp. Cercariae Infection. For the examination of the Indoplanorbis and Lymnaea intermediate snail hosts for Paramphistomum spp. cercariae infection, the snails were placed in water-filled specimen tubes for a period of 24 hours. After regular intervals of 60 minutes, the tubes were observed in light for the presence of cercariae. The snails were regarded infected if encysted cercariae emerged on the walls of the tube. Infected snails were isolated for further examination. Sometimes, for a long time, the snails did not protrude their bodies out of the shell, so the cercariae were not discharged. Such snails were reexamined until the snail shelled out their bodies. The snails were further examined under a stereomicroscope for confirmation of the infection with Paramphistomum spp. cercariae. The highly contractile cercariae with a tail were collected for further examination.

\subsection{Examination of the Paramphistomum spp. Cercariae.} The collected cercariae were examined under a microscope for the confirmation of Paramphistomum spp. infection. The 
Paramphistomum cercariae were identified according to the criteria outlined by Dinnik [21] and Eduardo [22]. The cercariae having Paramphistomum spp. rediae are shorter with a small pharynx lacking a collar and appendages in their bodies [23]. These cercariae are dark brown in color and sluggish. The prevalence of natural infection of each Indoplanorbis and Lymnaea intermediate snail host was determined by dividing the number of snails infected by Paramphistomum spp. cercariae by the total number of snails examined.

2.5. Meteorological Data Collection. The meteorological factors including pan evaporation, humidity, rainfall, and temperature were obtained from the Regional Meteorological Center, Peshawar, Government of Pakistan, in soft format (the only nearest station in Khyber Pakhtunkhwa, Pakistan).

2.6. Statistical Analysis. The data obtained were statistically analyzed in Excel sheets by applying the chi-square test $\left(\chi^{2}\right)$ by using SPSS. $P<0.05$ is considered statistically significant.

\section{Results}

3.1. Total Natural Paramphistomum spp. Infection in Indoplanorbis and Lymnaea Intermediate Snail Hosts. Table 1 shows the meteorological data of four adjacent districts of the province Khyber Pakhtunkhwa, Pakistan, during the period of October 2018 to September 2019.

A total of 2,706 snails were collected from the rivers of four districts of Khyber Pakhtunkhwa, Pakistan, including districts Mardan, Swabi, Charsadda, and Nowshehra. Of the total snails collected, 1539 belonged to the genus Indoplanorbis and 1167 to the genus Lymnaea (Figures 1(a), 1(b) and 2(a), 2(b), respectively). The water from the areas of collection had $\mathrm{pH}$ between 7.2 and 7.9, and vegetation of Nuphar lutea (lily) and Nelumbo lutea (lotus) was found abundant in the habitat. In the total collected snails, 10.38\% snails of both genera Indoplanorbis and Lymnaea were found infected with Paramphistomum spp. cercariae (Figure 3) with a significant difference $P<0.05\left(P=0.0028, \chi^{2}=14.08\right)$ (Table 2).

3.2. Monthwise and Areawise Natural Paramphistomum spp. Cercariae Infection in Indoplanorbis and Lymnaea Intermediate Snail Hosts. The peak Paramphistomum cercariae infection was recorded during July (12.7\%), followed by August $(12.0 \%)$, while no infection was recorded in December $(0.00 \%)$ and January $(0.00 \%)$ in the total 839 snails (371 of genus Indoplanorbis and 468 of genus Lymnaea) collected from the Kalpani River of district Mardan.

Of the total 535 snails collected from the Kabul River (Sardaryab) of district Charsadda, 243 belonged to the genus Indoplanorbis and 292 were from the genus Lymnaea. The infection rate was highest in October (19.4\%), and no infection was recorded in the months of January $(0.00 \%)$ and February $(0.00 \%)$.
The prevalence was highest in November (12.5\%), and the prevalence of Paramphistomum spp. cercariae was not recorded in the months of January $(0.00 \%)$ and February $(0.00 \%)$ (Table 2$)$, in the total 696 collected snail samples (303 of genus Indoplanorbis and 393 of genus Lymnaea) from the adjacent areas of Bara and Kabul rivers in district Nowshehra.

In the Indus River (Hund) of district Swabi, a total of 636 snails were collected, of which 249 belonged to the genus Indoplanorbis and 387 to the genus Lymnaea, with the highest infection rate in the month of July (26.2\%) and lowest in December (3.8\%), while no infection was recorded in the months of January $(0.00 \%)$ and February $(0.00 \%)$.

Furthermore, during the time of sample collection, the highest infection rate was recorded in July (15.6\%), followed by June (13.3\%), while no infection was recorded in the months of January $(0.00 \%)$ and February $(0.00 \%)$, showing a significant difference in the infection rate in different months $\left(\chi^{2}=8.467, P=0.0373\right)$.

Moreover, the highest total infection rate was recorded in the Indus River (Hund) of district Swabi (13.20\%), followed by the Kabul River (Sardaryab) of district Charsadda (11.40\%), Kalpani River of district Mardan (9.14\%), and adjacent areas of Bara and Kabul rivers in district Nowshehra (8.19\%) (Table 2).

3.3. Seasonwise Natural Paramphistomum spp. Cercariae Infection in Indoplanorbis and Lymnaea Intermediate Snail Hosts. For the determination of seasonwise natural prevalence of Paramphistomum spp. cercariae infection in Indoplanorbis and Lymnaea intermediate snail hosts, one year was divided into four groups as per season in the respective months. Winter consisted of five months (November 2018-February 2019), the spring season two months (March 2019-April 2019), the summer season four months (May 2019-August 2019), and the autumn season two months (October 2018 and September 2019). The results showed that the infection rate was at the peak during mid-summer (11.83\%), followed by autumn (11.25\%) and spring (7.07\%), whereas the lowest prevalence rate was recorded in the winter season (5.1\%), showing a significant difference in the infection in different seasons $(P<0.01)$ (Table 3$)$.

3.4. Natural Paramphistomum spp. Cercariae Infection in Indoplanorbis and Lymnaea Intermediate Snail Hosts Influenced by Meteorological Factors. It was found during the study that the prevalence of infection was positively correlated to minimum and maximum temperature, pan evaporation, humidity, and rainfall with highly significant differences. The data showed (Tables $1 \& 2$ ) that the disease incidence was highest in June and July when the highest average temperature $\left(32.5^{\circ} \mathrm{C}\right.$ and $\left.30.7^{\circ} \mathrm{C}\right)$ was recorded, the lowest relative humidity was $53.5 \%$ and $40.0 \%$, rainfall was $128.0 \mathrm{~mm}$ and $122.0 \mathrm{~mm}$, and pan evaporation was $224.3 \mathrm{~mm}$ and $200.3 \mathrm{~mm}$, respectively. Moreover, the infection was lowest in the months of January, December, and February when the lowest temperature $(11.9,13.45$, and $14.8^{\circ} \mathrm{C}$ ) was recorded, respectively. 
TABLE 1: Mean monthwise temperature $\left({ }^{\circ} \mathrm{C}\right)$, relative humidity (\%), rainfall $(\mathrm{mm})$, and pan evaporation (mm) during the study period in the adjacent districts of Khyber Pakhtunkhwa (October 2018 to September 2019).

\begin{tabular}{|c|c|c|c|c|c|c|c|c|}
\hline \multirow{2}{*}{ Time (months) } & \multicolumn{3}{|c|}{ Temperature $\left(\mathrm{C}^{\circ}\right)$} & \multicolumn{3}{|c|}{ Relative humidity (\%) } & \multirow{2}{*}{ Rainfall (\%) } & \multirow{2}{*}{ Pan evaporation $(\mathrm{mm})$} \\
\hline & Minimum & Maximum & Average & Morning & Evening & Average & & \\
\hline Oct 2018 & 17.3 & 31.9 & 24.6 & 82 & 48 & 65.0 & 0.0 & 78.0 \\
\hline Nov 2018 & 11.0 & 22.7 & 16.85 & 92 & 66 & 79.0 & 61.0 & 58.5 \\
\hline Dec 2018 & 5.9 & 23.0 & 14.45 & 82 & 52 & 67.0 & 12.3 & 47.1 \\
\hline Jan 2019 & 3.8 & 20.1 & 11.95 & 83 & 50 & 66.5 & 0.0 & 44.4 \\
\hline Feb 2019 & 7.9 & 23.6 & 15.75 & 83 & 48 & 65.5 & 36.5 & 51.8 \\
\hline Mar 2019 & 13.8 & 29.0 & 21.40 & 77 & 46 & 61.5 & 23.8 & 89.8 \\
\hline Apr 2019 & 18.1 & 32.5 & 25.30 & 76 & 49 & 62.5 & 102.3 & 102.9 \\
\hline May 2019 & 22.1 & 36.1 & 29.10 & 63 & 44 & 53.5 & 54.0 & 182.1 \\
\hline Jun 2019 & 25.8 & 41.2 & 33.50 & 66 & 41 & 53.5 & 19.0 & 225.3 \\
\hline Jul 2019 & 25.6 & 37.7 & 31.65 & 78 & 62 & 70.0 & 121.0 & 201.3 \\
\hline Aug 2019 & 26.6 & 37.1 & 31.85 & 80 & 63 & 71.5 & 25.6 & 167.9 \\
\hline Sep 2019 & 23.2 & 36.8 & 30.00 & 77 & 51 & 64.0 & 19.0 & 131.7 \\
\hline
\end{tabular}

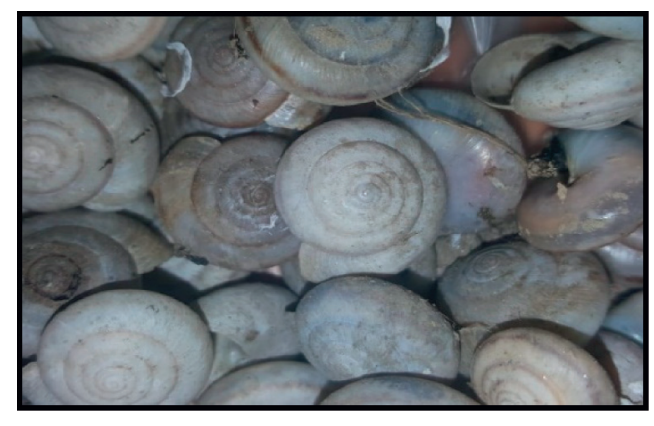

(a)

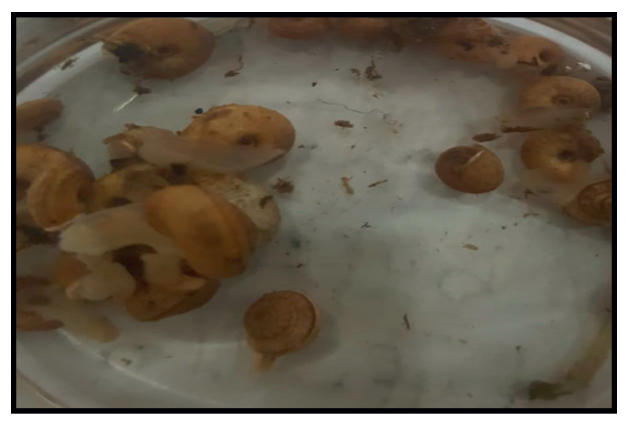

(b)

FIgURE 1: Snails belonging to the genera Indoplanorbis collected during the study for the investigation of the prevalence of Paramphistomum spp. cercariae (collection site: adjacent area of the river in district Swabi).

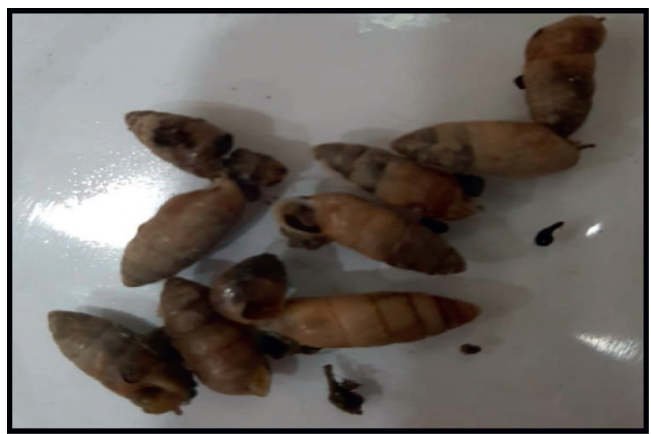

(a)

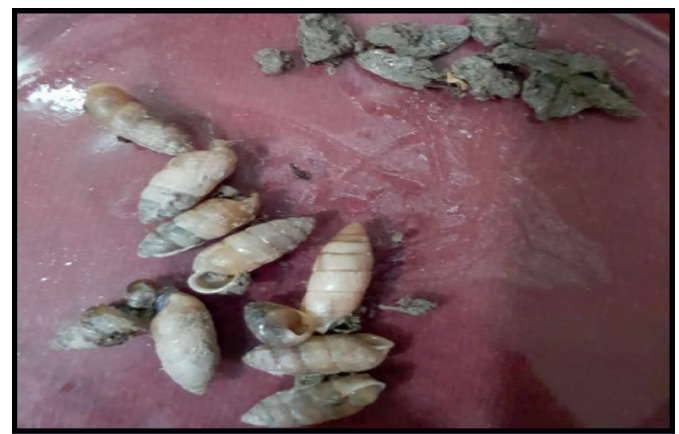

(b)

Figure 2: (a, b) Snails belonging to the genera Lymnaea collected during the study for the investigation of the prevalence of Paramphistomum spp. cercariae (collection site: adjacent area of the river in district Charsadda).

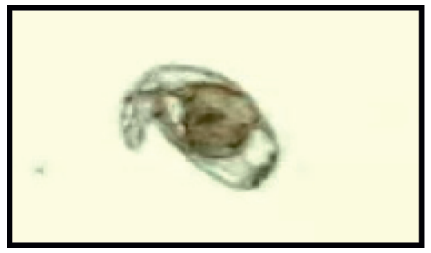

FIgURE 3: Cercariae $(100 \times)$ of Paramphistomum spp. found in the snail belonging to the genus Lymnaea. 
TABLE 2: Areawise and monthwise prevalence of Paramphistomum spp. cercariae infection in Indoplanorbis and Lymnaea intermediate snail hosts in various districts of Khyber Pakhtunkhwa, Pakistan.

\begin{tabular}{|c|c|c|c|c|c|c|c|c|}
\hline \multirow[b]{2}{*}{ Areas } & \multirow[b]{2}{*}{ Month-year } & \multicolumn{2}{|c|}{ Snail hosts } & \multirow[b]{2}{*}{$\begin{array}{c}\text { Total } \\
\text { observed }\end{array}$} & \multirow[b]{2}{*}{$\begin{array}{c}\text { Infected with } \\
\text { Paramphistomum spp. }\end{array}$} & \multirow[b]{2}{*}{$\begin{array}{c}\text { Rate of } \\
\text { infection (\%) }\end{array}$} & \multirow[b]{2}{*}{$\chi^{2}$} & \multirow[b]{2}{*}{$P$} \\
\hline & & $\begin{array}{l}\text { Lymnaea } \\
\text { spp. }\end{array}$ & $\begin{array}{l}\text { Indoplanorbis } \\
\text { spp. }\end{array}$ & & & & & \\
\hline \multirow{13}{*}{$\begin{array}{l}\text { River Kalpani of district } \\
\text { Mardan }\end{array}$} & Oct-18 & 38 & 27 & 65 & 04 & 6.1 & & \\
\hline & Nov-18 & 30 & 13 & 43 & 03 & 6.9 & & \\
\hline & Dec-18 & 10 & 05 & 15 & 00 & 0.0 & & \\
\hline & Jan-19 & 12 & 10 & 22 & 00 & 0.0 & & \\
\hline & Feb-19 & 15 & 11 & 26 & 01 & 3.8 & & \\
\hline & Mar-19 & 29 & 26 & 55 & 06 & 10.9 & & \\
\hline & Apr-19 & 48 & 52 & 100 & 08 & 8.0 & & \\
\hline & May-19 & 42 & 44 & 86 & 08 & 9.3 & & \\
\hline & Jun-19 & 68 & 42 & 110 & 12 & 110.9 & & \\
\hline & Jul-19 & 54 & 32 & 86 & 11 & 12.7 & & \\
\hline & Aug-19 & 58 & 50 & 108 & 13 & 12.0 & & \\
\hline & Sep-19 & 63 & 60 & 123 & 13 & 10.5 & & \\
\hline & Total & 467 & 372 & 839 & 79 & 9.41 & & \\
\hline \multirow{13}{*}{$\begin{array}{l}\text { Kabul River (Sardaryab) of } \\
\text { district Charsadda }\end{array}$} & Oct-18 & 19 & 17 & 36 & 7 & 19.4 & \multirow{13}{*}{8.467} & \multirow{13}{*}{0.037} \\
\hline & Nov-18 & 22 & 12 & 34 & 3 & 8.8 & & \\
\hline & Dec-18 & 06 & 05 & 11 & 1 & 9.0 & & \\
\hline & Jan-19 & 04 & 03 & 7 & 00 & 0.0 & & \\
\hline & Feb-19 & 04 & 03 & 7 & 00 & 0.0 & & \\
\hline & Mar-19 & 03 & 02 & 5 & 00 & 0.0 & & \\
\hline & Apr-19 & 28 & 19 & 47 & 02 & 4.25 & & \\
\hline & Мay-19 & 14 & 11 & 25 & 02 & 8.00 & & \\
\hline & Jun-19 & 23 & 20 & 43 & 04 & 9.3 & & \\
\hline & Jul-19 & 65 & 52 & 117 & 16 & 13.6 & & \\
\hline & Aug-19 & 62 & 58 & 120 & 14 & 11.6 & & \\
\hline & Sep-19 & 42 & 41 & 83 & 12 & 14.4 & & \\
\hline & Total & 292 & 243 & 535 & 61 & 11.40 & & \\
\hline \multirow{13}{*}{$\begin{array}{l}\text { Adjacent areas of Bara and } \\
\text { Kabul rivers in district } \\
\text { Nowshehra }\end{array}$} & Oct-18 & 21 & 19 & 40 & 2 & 5.0 & & \\
\hline & Nov-18 & 13 & 11 & 24 & 3 & 12.5 & & \\
\hline & Dec-18 & 10 & 02 & 12 & 1 & 8.3 & & \\
\hline & Jan-19 & 08 & 01 & 09 & 00 & 0.0 & & \\
\hline & Feb-19 & 06 & 1 & 7 & 00 & 0.0 & & \\
\hline & Mar-19 & 20 & 1 & 21 & 00 & 0.0 & & \\
\hline & Apr-19 & 31 & 22 & 53 & 00 & 3.7 & & \\
\hline & May-19 & 35 & 29 & 64 & 03 & 4.6 & & \\
\hline & Jun-19 & 38 & 30 & 68 & 05 & 7.3 & & \\
\hline & Jul-19 & 85 & 81 & 166 & 17 & 10.24 & & \\
\hline & Aug-19 & 73 & 62 & 135 & 13 & 9.6 & & \\
\hline & Sep-19 & 53 & 44 & 97 & 11 & 11.3 & & \\
\hline & Total & 393 & 303 & 696 & 57 & 8.19 & & \\
\hline \multirow{7}{*}{$\begin{array}{l}\text { Indus River (Hund) of } \\
\text { district }\end{array}$} & Oct-18 & 46 & 39 & 85 & 08 & 9.4 & & \\
\hline & Nov-18 & 32 & 12 & 44 & 06 & 13.6 & & \\
\hline & Dec-18 & 20 & 06 & 26 & 01 & 3.8 & & \\
\hline & Jan-19 & 15 & 05 & 20 & 00 & 0.00 & & \\
\hline & Feb-19 & 19 & 06 & 25 & 00 & 0.00 & & \\
\hline & Mar-19 & 23 & 04 & 27 & 02 & 7.4 & & \\
\hline & Apr-19 & 10 & 07 & 17 & 03 & 17.6 & & \\
\hline
\end{tabular}

\section{Discussion}

Snails play an essential role in the spread and transmission of paramphistomosis by acting as a vector including genera Indoplanorbis and Lymnaea. In Pakistan, the ecological conditions are appropriate for the survival of various species of snails. During the present study, 2,706 snails were collected from different regions of the province Khyber Pakhtunkhwa and $10.30 \%$ were found infected with Paramphistomum spp. cercariae.
In all four selected study sites, the highest infection rate was recorded in the Indus River (Hund) of district Swabi (13.20\%), which might be due to the reason that crop grown in abundance in the respective area leads to water logging that helps in snail reproduction and breeding and for the metacercariae and cercariae of Paramphistomum species. Different environmental conditions and management correlated with the difference of snail prevalence in different locations of the country. Our findings can be co-related with the findings of another study conducted in the district Gujranwala of 
TABle 3: Seasonwise prevalence of Paramphistomum spp. cercariae infection in Indoplanorbis and Lymnaea intermediate snail hosts in various districts of Khyber Pakhtunkhwa, Pakistan.

\begin{tabular}{lccccc}
\hline Seasons & \multicolumn{2}{c}{$\begin{array}{c}\text { Snail hosts } \\
\text { Lymnaea spp. Indoplanorbis spp. }\end{array}$} & $\begin{array}{c}\text { Total } \\
\text { observed }\end{array}$ & $\begin{array}{c}\text { Infected with Paramphistomum } \\
\text { spp. }\end{array}$ & $\begin{array}{c}\text { Rate of infection } \\
\text { (\%) }\end{array}$ \\
\hline Winter: Nov 2018-Feb 2019 & 226 & 106 & 332 & 17 & $5.1 \%{ }^{*}$ \\
Spring: Mar 2019-Apr 2019 & 192 & 133 & 325 & 23 & $7.07 \%{ }^{*}$ \\
Summer: May 2019-Aug 2019 & 796 & 640 & 1463 & 170 & $11.83 \%^{* *}$ \\
Autumn: Oct 2018 \& Sep 2019 & 326 & 287 & 613 & 69 & $11.25 \% \%^{* *}$ \\
\hline
\end{tabular}

*Significant $(P<0.05)$, and ${ }^{* *}$ highly significant $(P<0.001)$.

province Punjab, Pakistan, on the incidence of paramphistomosis in cattle $[24,25]$. In a previous study, the environmental data from the farms of origin of the necropsied cows were used in Bayesian geostatistical models to forecast the prospect of infection by $C$. daubneyi throughout the region. These findings confirmed the role of environmental risk aspects in elucidating the geographical heterogeneity in the probability of infection in beef and dairy cattle [26]. A positive correlation of infection rate with pan evaporation, humidity, rainfall, and temperature was observed. The current study findings showed that trematodal cercariae are not found in all seasons but are found in specific times of the year. Two periods of the highest incidence of metacercariae and cercariae of Paramphistomum species were observed in the months of July-August and October, whereas the lowest infection rate was observed during the months of December-February. Moreover, the results showed that the infection rate was at a peak during the summer season, which might be due to the factors of optimum temperature, relative rainfall, and humidity. These factors play a significant role in the propagation of the Paramphistomum species, and thus a considerable difference was found in the rate of incidence of paramphistomosis in correlation with temperature, humidity, and rainfall in each season, showing agreement with the earlier studies in different regions $[24,25,27-30]$ and disagreement to the other studies [31, 32].

\section{Conclusion}

It is the first report on the prevalence of Paramphistomum species cercariae in the Indoplanorbis and Lymnaea intermediate snail hosts in the study area. It was concluded from the study that meteorological factors contribute to the prevalence of Paramphistomum species cercariae in Indoplanorbis and Lymnaea, acting as vectors for the disease paramphistomosis that may lead to the increased intensity of infection outbreaks of the parasite population in humans and domestic animals.

\section{Data Availability}

The data used to support the findings are included within the article.

\section{Conflicts of Interest}

The authors declare that they have no conflicts of interest.

\section{Acknowledgments}

The authors would like to thank Researchers Supporting Project (no. RSP- 2021/110) at King Saud University, Riyadh, Saudi Arabia, for financial support.

\section{References}

[1] T. M. Murphy, E. P. Power, C. Sanchez-Miguel, M. J. Casey, D. P. Toolan, and J. G. Fagan, "Paramphistomosis in Irish cattle," The Veterinary Record, vol. 162, pp. 831-832, 2008.

[2] M. Gonzalez Warleta, S. Lladosa, J. A. Castro-Hermida et al., "Bovine paramphistomosis in Galicia (Spain): prevalence, intensity, aetiology and geospatial distribution of the infection," Veterinary Parasitology, vol. 191, no. 3-4, pp. 252-263, 2013.

[3] O. W. Olsen, Animal Parasite: Their Life Cycle and Ecology, pp. 273-274, Dover's Publication Baltimore, Maryland, 1974.

[4] M. V. K. Sukhdeo and S. C. Sukhdeo, "Trematode behaviours and the perceptual worlds of parasites," Canadian Journal of Zoology, vol. 82, no. 2, pp. 292-315, 2004.

[5] P. F. Rolfe, J. C. Boray, P. Nichols, and G. H. Collins, "Epidemiology of paramphistomosis in cattle," International Journal for Parasitology, vol. 21, no. 7, pp. 813-819, 1991.

[6] N. Rafiq, S. Niaz, I. Zeb, S. Ayaz, I. Da Silva Vaz, and A. Ali, "Molecular characterization of Paramphistomum cervi in buffaloes," Acta Scientiae Veterinariae, vol. 48, 2020.

[7] M. Arias, C. Lomba, V. Dacal et al., "Prevalence of mixed trematode infections in an abattoir receiving cattle from northern Portugal and north-west Spain," The Veterinary Record, vol. 168, no. 15, p. 408, 2011.

[8] C. Mage, H. Bourgne, J.-M. Toullieu, D. Rondelaud, and G. Dreyfuss, "Fasciola hepatica and Paramphistomum daubneyi: changes in prevalences of natural infections in cattle and in Lymnaea truncatula from central France over the past 12 years," Veterinary Research, vol. 33, no. 5, pp. 439-447, 2002.

[9] D. M. Pfukenyi, S. Mukaratirwa, A. L. Willingham, and J. Monrad, "Epidemiological studies of amphistome infections in cattle in the highveld and lowveld communal grazing areas of Zimbabwe," Onderstepoort Journal of Veterinary Research, vol. 72, no. 1, pp. 67-86, 2005.

[10] M. A. Raza, S. Murtaza, H. A. Bachaya, and A. Hussain, "Prevalence of paramphistomumcervi in ruminants slaughtered in district MuzaffarGarh," The Veterinary Journal, vol. 29, no. 4, pp. 214-215, 2009.

[11] L. S. Robert and G. D. Schmidt, Foundation of ParasitologyMcGraw Hill293 pages, McGraw Hill, 8th edition, 2008.

[12] S. Ali, M. Q. Khan, M. Qayyum, and M. F. U. Khan, "Prevalence ofgastrointestinal parasites in sheep and goats 
maintained at NARC, Islamabad, Pakistan," Pakistan Veterinary Journal, vol. 20, no. 3, pp. 157-158, 2000.

[13] I. R. M. Al-Shaibani, M. S. Phulan, A. Arijo, and T. A. Qureshi, "Epidemiology of ovine gastrointestinal nematodes inHyderabad district, Pakistan," Pakistan Veterinary Journal, vol. 28, no. 3, pp. 125-130, 2008.

[14] M. Ijaz, M. S. Khan, M. Avais, K. Ashraf, and M. M. Ali, "Infectionrate and chemotherapy of various helminths in goats inand around Lahore," Pakistan Veterinary Journal, vol. 28 , no. 4, pp. 167-170, 2008.

[15] C. Ollerenshaw, "Some observations on the epidemiology of fascioliasis in relation to the timing of molluscicide applications in the control of the disease," The Veterinary Record, vol. 88, no. 6, pp. 152-164, 1971.

[16] U. Khan and A. Maqbool, "Prevalence of paramphistomosis in relation to meteorological factors," Pakistan Journal of Zoology, vol. 44, pp. 823-828, 2012.

[17] L. Liu, M. M. Mondal, M. A. Idris et al., "The phylogeography of Indoplanorbis exustus (gastropoda: Planorbidae) in Asia," Parasites \& Vectors, vol. 3, no. 1, p. 57, 2010.

[18] U. J. Khan, A. Tanveer, M. Azhar, and S. Masood, "Epidemiological studies of pharamphistomiosis in cattle," Veterinary Archives, vol. 78, pp. 243-251, 2008.

[19] N. Rafiq, S. Z. Ahmad, G. Yasmeen et al., "Identification of terrestrial gastropods families found in district Swat, Pakistan," Brazilian Journal of Biology, vol. 83, 2021.

[20] B. J. Smith, Field Guide to the Non-marine Molluscs of South Eastern Australia, Australian National University Press, Canberra, Australia, 1979.

[21] J. A. Dinnik, "Paramphistomum daubneyi sp. nov. from cattle and its snail host in the Kenya Highlands," Parasitology, vol. 52, no. 1-2, pp. 143-151, 1962.

[22] S. L. Eduardo, "The taxonomy of the family Paramphistomidae Fischoeder, 1901 with special reference to the morphology of species occurring in ruminants. III. Revision of the genus Calicophoron Näsmark, 1937, 1937," Systematic Parasitology, vol. 5, no. 1, pp. 25-79, 1983.

[23] W. M. Lotfy, L. M. Lotfy, L. M. Lotfy, and R. M. Khalifa, "An overview of cercariae from the Egyptian inland water snails," Journal of Coastal Life Medicine, vol. 5, no. 12, pp. 562-574, 2017.

[24] S. Niaz, "Epidemology, seriodiagnosis and therapy of schistosomiasis in Human, Cows and Buffaloes. A thesis submitted to," University of Punjab for the Partial Fulfillment of Requirement, Lahore, Pakistan, Ph. D Degree, 2010.

[25] U. J. Khan and M. Azhar, "Prevalence of pharamphistomiosis in relation to meteorological factors," Pakistan Journal of Zoology, vol. 4, no. 3, pp. 823-828, 2012.

[26] M. González-Warleta, S. Lladosa, J. Castro-Hermida et al., "Bovine paramphistomosis in Galicia (Spain): prevalence, intensity, aetiology and geospatial distribution of the infection," Veterinary Parasitology, vol. 191, no. 3-4, pp. 252-263, 2013.

[27] G. Dreyfuss, A. Novobilský, P. Vignoles et al., "Prevalence and intensity of infections in the lymnaeid snail Omphiscola glabra experimentally infected with Fasciola hepatica, Fascioloides magna and Paramphistomum daubneyi," Journal of Helminthology, vol. 81, no. 1, pp. 7-12, 2007.

[28] D. M. Pfukeni, S. Mukaratirwa, A. L. Willingham, and J. Monrad, "Epidemological studies of amphistome infections in cattle in the highveld and Iowveld communal grazing areas of Zimbabwe," Onderstepoort Journal of Veterinary Research, vol. 72, no. 1, pp. 67-86, 2005b.

[29] D. M. Pfukeni, J. Monrad, and S. Mukaratirwa, "Epidemiology and control of trematode infections in cattle in Zimbabwe: A review," Journal of the South African Veterinary Association, vol. 76, no. 1, pp. 9-17, 2005a.

[30] R. C. Joao and S. M. B. Fernando, "The effects of temperature changes on the infection rate of Biomphalariaglabrta with Schistosomamansoni," Memorias do Institute Oswaldo Cruz, vol. 101, no. 2, pp. 223-224, 2006.

[31] D. L. Ferrell, N. J. Negovetich, T. Wetze, and E. J. Wetzel, "Effect of temperature on the infectivity of metacercariae ofzygocotyle lunata (digenea: paramphistomidae)," The Journal of Parasitology, vol. 87, no. 1, pp. 10-13, 2001.

[32] K. N. De Kock and C. T. Wolmarans, "Distribution, habitats and role as intermediate host of the freshwater snail, Bulinusforekalii in South Africa. Onderstepoort," Journal of Veterinary Research, vol. 72, no. 2, pp. 165-174, 2005. 